\title{
Performance Analysis of the Consumer Loans: A Regional Study in Turkey
}

\author{
Metin Allahverdi ${ }^{1}$, Ali Alagöz ${ }^{2}$ \\ Selcuk University, Konya Turkey
}

\begin{abstract}
In this study was conducted regional analysis of consumer loans performances for 2016:12019:2 periods in Turkey. In the study was used of the statistical regions created in accordance with the European Union system of Turkey. Accordingly, cluster analysis was used at the level of "level 2" consisting of 26 regions. According to the analysis, the regions are clustered in four classes. In this study, the consumer loan performance of the cluster members was presented in comparison with the economic variables of the regions. According to the comparison results, although some economic values of the regions were good, loan performance was found to be below average.
\end{abstract}

Keywords: Turkey's Banking Sector, Consumer Loans, Non-Performing Consumer Loans, Cluster Analysis.

\section{Introduction}

Loans have an important share in Turkey's banking sector. According to the BDDK data of March 2019, loans account for 60\% of total assets in the banking sector (BDDK, 2019: 1-2). The total deposit ratio of total loans increased from 0.83 in 2010 to 1.05 in March 2019. Consumer loans, which size of TL 2.518 billion in the sector, account for $20 \%$ of the total loans (BDDK, 2019: 10-11).

Consumer loans, which was applied in 1988 for the first time in Turkey, are defined as loans to individuals or real persons for the purchase of any goods or services other than for commercial purposes, to be repaid under certain conditions (Uzunlar, 1990: 59; Parasız, 1997: 180). Consumer loans are classified as housing loans, vehicle loans, personal financial loans and credit cards in Turkey (Yüksel and Özsar1, 2016: 6). 


\section{MANAGEMENT, BUSINESS \& FINANCE}

With political stability that began with the 2002 election of government;

- the decrease in inflation,

- increase in economic growth,

- increase in consumer income,

- the establishment of legal regulations in the banking sector and - lower interest rates have also led to a strong increase in demand for consumer loans.

Figure 1: Turkey's Consumer Loans (million TRY)

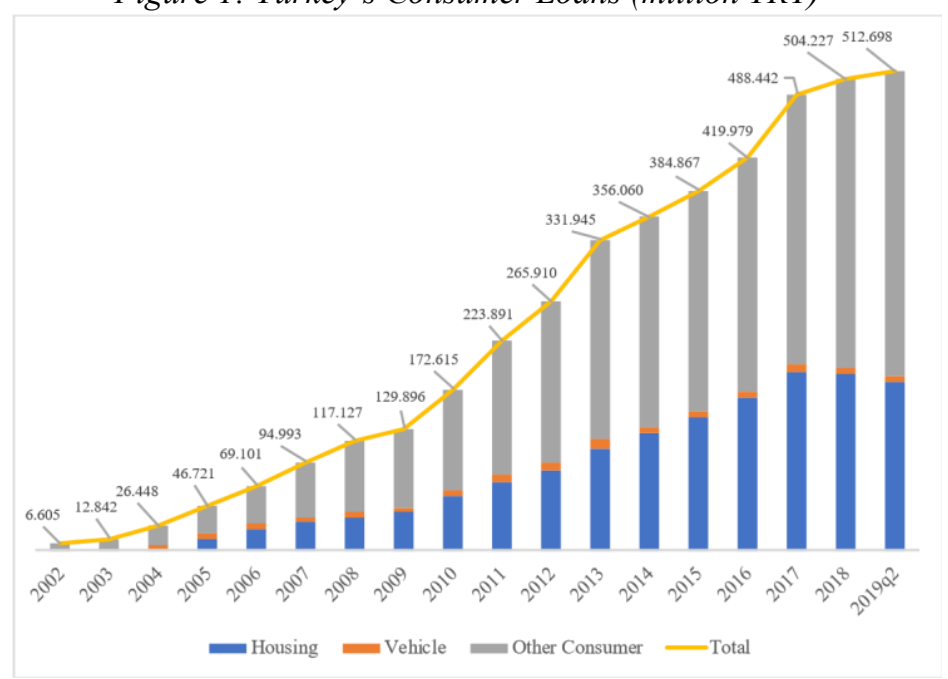

Source: It is prepared with data obtained from the Banking Regulation and Supervision Agency web site.

Consumer loans, which were approximately 6,5 million TRY in 2002, increased to approximately 513 billion TRY in the second quarter of 2019 (see Figure 1). Most of this borrowing consists of individual credit cards and personal finance credits (gray column).

With the increase in the use of the loan, the non-performing loans have increased in parallel with the economic situation of the country. The non-performing loans mean that the principal and interest are not paid even though their maturities have arrived (Utku, 2018: 66). The nonperforming loans ratio to total loans in Turkey's banking sector was realized as $4.05 \%$ in March 2019 (BDDK, 2019: 14). Turkey's non-performing consumer loans are shown as follows. 


\section{|||||ICMBF}

$2^{\text {nd }}$ International Conference on Advanced Research in

MILAN, ITALY

\section{MANAGEMENT, BUSINESS \& FINANCE

Figure 2: Turkey's Non-Performing Consumer Loans (million TL)

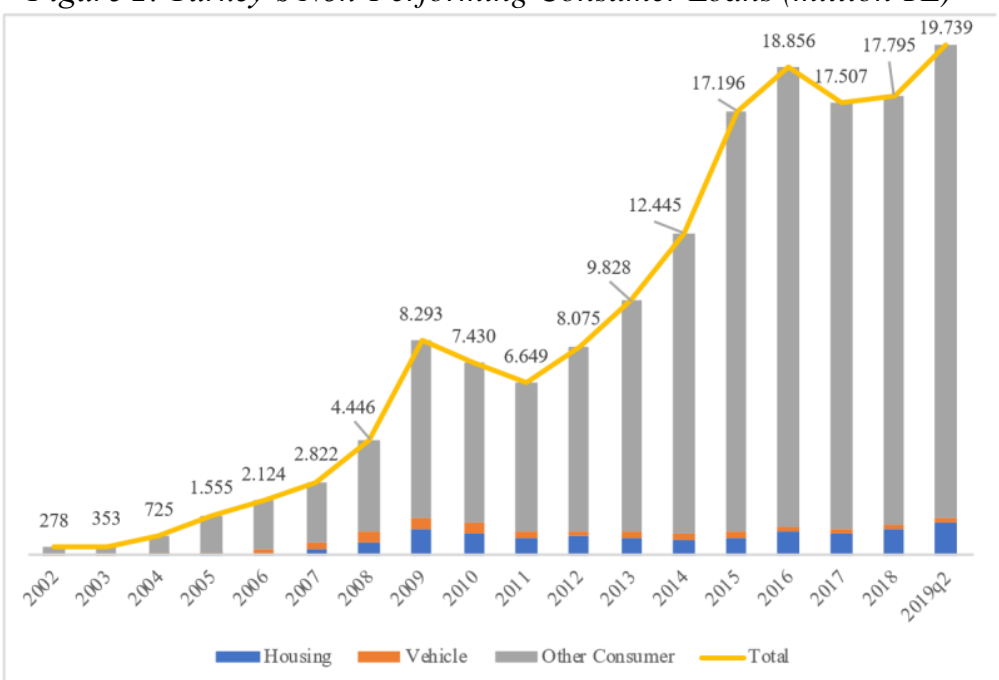

Source: It is prepared with data obtained from the Banking Regulation and Supervision Agency web site.

As seen in Figure 2, non-performing consumer loans increased by approximately $7000 \%$ from 2002 to 2019. Particularly in the last 5 years, the amount of non-performing loans of other consumer loans consisting of personal financial loans and credit cards has been higher than housing and vehicle loans. The non-performing loans are constituted approximately $3.78 \%$ of the total consumer loans.

Figure 3: Turkey's Non-Performing Consumer Loans Rates (\%)

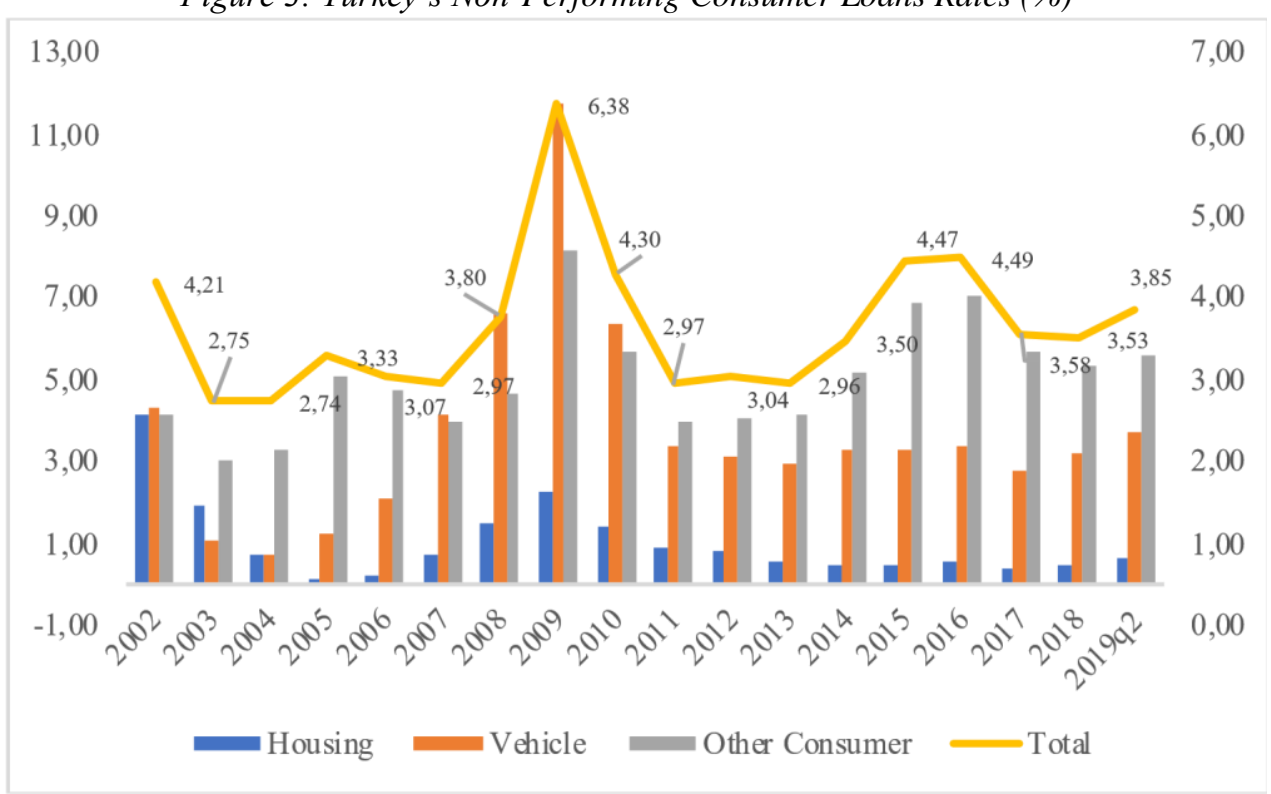

Source: It is prepared with data obtained from the Banking Regulation and Supervision Agency web site.

When the non-performing loan ratios according to the components of consumer loans are examined, the rates of vehicle loans and other loans have increased rapidly especially during 
the 2008 global crisis period. Recently, the high non-performing loan ratio in credit cards and personal financial loans has attracted attention.

The non-performing loan ratio, known as the ratio of receivables to total loans (Gürel, 2002), is also used as a credit performance indicator. The high-performance ratio indicates that the credit quality of the bank and thus the profitability of the bank is low (Sarıtaş vd., 2016: 91). It is considered that the performance ratios of loans are important data in the evaluations on finance and economy. Therefore, the importance of research on issues such as the detection of these data, its relation to other economic variables, its regional development, and the uncovering of the cause of the increases in data emerge. Within the framework of this importance, the study conducted a regional analysis of the consumer loan performance of banks in Turkey and their relationship with various economic variables were demonstrated.

\section{Methodology}

In this study, Turkey's consumer loan performances for the periods 2016:1-2019:2 were analyzed using the "Nomenclature of Territorial Units for Statistics" used since 2002 in accordance with the European Union.

With the government's decision issued in 2002 (Official Newspaper No: 24884), Turkey is divided into three levels as a statistical region. Of these, the statistical regional units under "Level 3" are 81 units and are at the provincial level. Each province defines a statistical zone unit. "Level 2" statistical region units are defined as a result of grouping neighboring provinces under "Level 3" and they have 26 members. "Level 1" statistical regional units are defined as the result of grouping the "Level 2" statistical regional units and they have 12 members. In this study, analyses were conducted on Level 2 statistical region units.

In this study, regions at "Level 2" level were classified by cluster analysis method. Cluster analysis is used as a general data reduction technique to improve large data sets and obtain more general and easily managed information (Allahverdi and Alagöz, 2019: 448). In cluster analysis, Level 2 regions were classified using "wards method" and "square Euclidean distance" method. SPSS 22 and Microsoft Excel 2016 program were used for analysis. 


\section{MANAGEMENT, BUSINESS \& FINANCE}

\section{Variables of Research}

The variables used in the study are shown in the table below.

Table 1: Variables used in cluster analysis

\begin{tabular}{|c|c|c|c|c|}
\hline Main Variable & Sub Variable & Variable Code & Period & Data Source \\
\hline \multirow{3}{*}{$\begin{array}{l}\text { Consumer Loan } \\
\text { Performance Rates } \\
\text { (Regional) }\end{array}$} & $\begin{array}{l}\text { Housing Loan Performance } \\
\text { Rate }\end{array}$ & HLPR (\%) & $2016: 1-2019: 2$ & BRSA \\
\hline & Vehicle Loan Performance Rate & VLPR $(\%)$ & $2016: 1-2019: 2$ & BRSA \\
\hline & $\begin{array}{l}\text { Other Consumer Loan } \\
\text { Performance Rate } \\
\text { (personal financial loan and } \\
\text { credit card) }\end{array}$ & OCLPR (\%) & $2016: 1-2019: 2$ & BRSA \\
\hline
\end{tabular}

In the analysis, the consumer loan performance ratio values of the new regions obtained as a result of clustering were compared with the following variables.

Table 2: Variables used in comparison

\begin{tabular}{|l|l|l|l|l|}
\hline Main Variable & Sub Variable & Variable Code & Period & Data Source \\
\hline $\begin{array}{l}\text { Demographic Variables } \\
\text { (Regional) }\end{array}$ & Population & POP (Per) & 2018 & TSI \\
\hline \multirow{4}{*}{$\begin{array}{l}\text { Economic Variables } \\
\text { (Regional) }\end{array}$} & Consumer Price Index & CPI (\%) & $2016: 1-2019: 2$ & TCMB \\
\cline { 2 - 5 } & Per Capita GDP & PerGDP (TL) & 2016,2017 & TSI \\
\cline { 2 - 5 } & $\begin{array}{l}\text { Household Disposable } \\
\text { Income }\end{array}$ & HDI (TL) & $2014,2016,2018$ & TSI \\
\cline { 2 - 5 } & Employment Rate & ER (\%) & $2016,2017,2018$ & TSI \\
\cline { 2 - 5 } & Unemployment Rate & UR (\%) & $2016,2017,2018$ & TSI \\
\hline
\end{tabular}

In the analysis, mean data of periods belonging to variables were used.

\section{Findings}

The cluster analysis was conducted with the mean of the consumer loan performance ratio. Looking at the "dendrogram" graph which obtained as a result of the analysis, the regions were classified into four clusters at the nearest distance. The resulting four clusters are shown on the map of Turkey. 


\section{|||||ICMBF}

$2^{\text {nd }}$ International Conference on Advanced Research in

MILAN, ITALY

\section{MANAGEMENT, BUSINESS \& FINANCE}

Figure 4: Dendrogram graph and representation of results on the map of Turkey

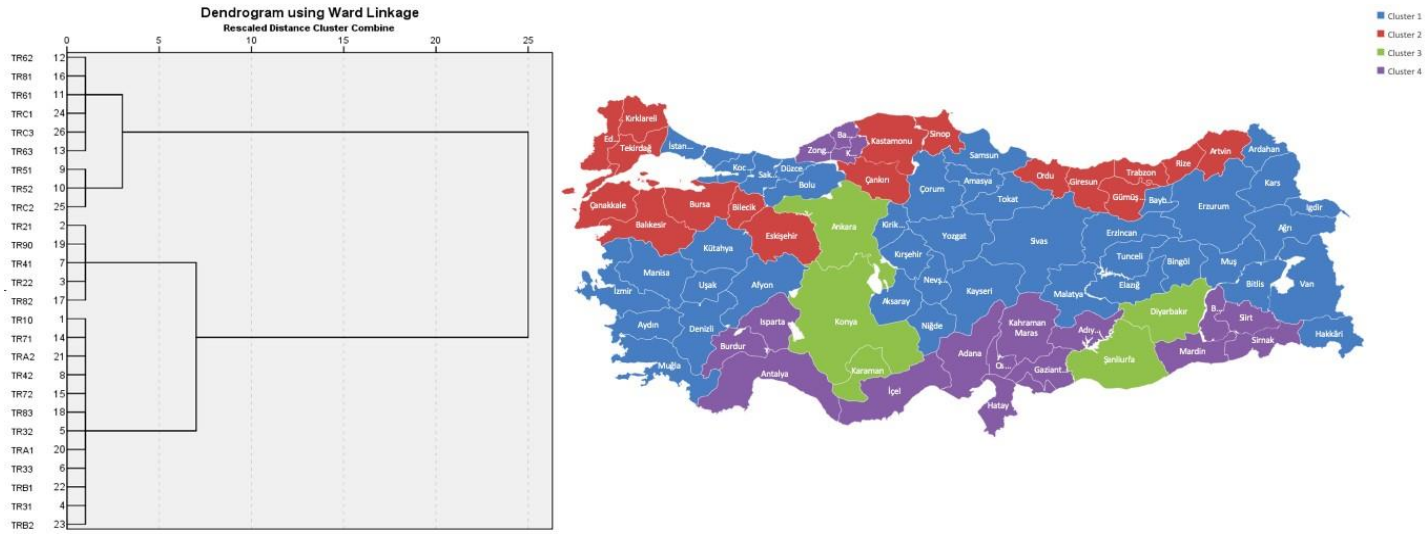

As can be seen from the map, the 1st cluster is the largest cluster with 12 regions and 41 cities, while cluster 3 is the smallest cluster consisting of 3 regions and 5 cities. The descriptive statistics of the clusters are as shown in Table 3.

Table 3: Properties of clusters formed as a result of analysis

\begin{tabular}{|l|r|r|r|r|r|r|r|}
\hline & Total Regions & Total City & Min & Max & Mean Std. Deviation & Std. Error \\
\hline Cluster 1 & 12 & 41 & 2,49 & 3,06 & 2,8072 &, 15847 &, 04575 \\
\hline Cluster 2 & 5 & 17 & 1,93 & 2,36 & 2,1904 &, 17397 &, 07780 \\
\hline Cluster 3 & 3 & 5 & 3,75 & 4,07 & 3,9006 &, 16185 &, 09344 \\
\hline Cluster 4 & 6 & 18 & 3,26 & 3,63 & 3,4031 &, 16541 &, 06753 \\
\hline Total & 26 & 81 & 1,93 & 4,07 & 2,9522 &, 55350 &, 10855 \\
\hline
\end{tabular}

According to the cluster analysis results, the best regions in consumer loan performance were grouped in the second cluster and the worst performing regions were in the third cluster. According to the data, approximately $70 \%$ of the provinces in Turkey performed positively, below average, while $30 \%$ performed negatively above average. 


\section{MANAGEMENT, BUSINESS \& FINANCE}

Table 4: Member regions and features of Cluster 1

\begin{tabular}{|c|c|c|c|c|c|c|c|c|c|}
\hline Regions & HLPR & VLPR & OCLRP & POP & $\begin{array}{l}\text { CPI } \\
(\%)\end{array}$ & $\begin{array}{l}\text { PerGDP } \\
\text { (TL) }\end{array}$ & HDI (TL) & $\operatorname{ER}(\%)$ & UR (\%) \\
\hline TR10 & 0,48 & 2,63 & 5,59 & 15.067 .724 & 0,2172 & $59.987,00$ & $65.282,91$ & 49,43 & 13,30 \\
\hline TR31 & 0,48 & 2,64 & 5,40 & 4.320 .519 & 0,2477 & $41.425,50$ & $50.158,31$ & 47,87 & 13,93 \\
\hline TR32 & 0,48 & 2,91 & 4,63 & 3.093 .015 & 0,2557 & $30.974,00$ & $35.636,31$ & 51,60 & 6,90 \\
\hline TR33 & 0,44 & 3,70 & 4,19 & 3.100 .666 & 0,2436 & $29.171,50$ & $35.702,57$ & 49,93 & 5,93 \\
\hline TR42 & 0,53 & 3,67 & 4,56 & 3.878 .979 & 0,2292 & $46.562,00$ & $47.709,08$ & 48,67 & 10,57 \\
\hline TR71 & 0,47 & 3,48 & 4,71 & 1.603 .688 & 0,2347 & $24.969,00$ & $37.645,40$ & 45,47 & 11,90 \\
\hline TR72 & 0,49 & 4,10 & 4,28 & 2.461 .269 & 0,2446 & $27.589,50$ & $40.160,31$ & 43,50 & 11,17 \\
\hline TR83 & 0,50 & 3,83 & 4,84 & 2.822 .353 & 0,2458 & $23.752,50$ & $38.488,27$ & 49,53 & 7,00 \\
\hline TRA1 & 0,44 & 4,01 & 3,83 & 1.086 .156 & 0,2390 & $23.100,50$ & $38.891,11$ & 46,07 & 6,00 \\
\hline TRA2 & 0,75 & 3,94 & 3,92 & 1.124 .898 & 0,2545 & $15.839,50$ & $35.590,74$ & 48,07 & 5,23 \\
\hline TRB1 & 0,34 & 2,85 & 4,27 & 1.762 .077 & 0,2426 & $21.641,50$ & $36.234,54$ & 46,90 & 7,97 \\
\hline TRB2 & 0,67 & 3,41 & 4,09 & 2.167 .642 & 0,2527 & $14.277,00$ & $33.907,81$ & 39,43 & 14,50 \\
\hline Mean & 0,51 & 3,43 & 4,53 & 3.540 .749 & 0,2423 & $29.940,79$ & $41.283,95$ & 47,21 & 9,53 \\
\hline
\end{tabular}

Cluster 1 has the most regions in Turkey. The total number of provinces constitutes $50 \%$. In this respect, it has important indicators. Accordingly, most cities in Turkey perform better than average performance. In this cluster, regions with good and bad economic values have come together. For example, Turkey's richest and most populous region of Istanbul and where per capita income is the lowest Van, Muş, Bitlis, and Hakkari, which consists of TRB2 took place in this cluster. 


\section{MANAGEMENT, BUSINESS \& FINANCE}

Table 5: Member regions and features of Cluster 2

\begin{tabular}{|c|c|c|c|c|c|c|c|c|c|}
\hline Regions & HLPR & VLPR & OCLRP & POP & $\begin{array}{l}\text { CPI } \\
(\%)\end{array}$ & $\begin{array}{l}\text { PerGDP } \\
\text { (TL) }\end{array}$ & HDI (TL) & ER (\%) & UR (\%) \\
\hline TR21 & 0,42 & 2,14 & 4,28 & 1.802 .315 & 0,2319 & $38.900,50$ & $50.238,55$ & 54,33 & 7,77 \\
\hline TR22 & 0,42 & 2,23 & 3,67 & 1.767 .237 & 0,2380 & $31.535,00$ & $33.731,73$ & 46,13 & 6,13 \\
\hline TR41 & 0,32 & 2,55 & 4,22 & 4.089 .156 & 0,2284 & $39.776,00$ & $46.480,21$ & 46,80 & 9,33 \\
\hline TR82 & 0,32 & 2,01 & 3,45 & 819.468 & 0,2488 & $25.135,50$ & $38.389,53$ & 54,03 & 5,17 \\
\hline TR90 & 0,46 & 2,64 & 3,74 & 2.719 .113 & 0,2531 & $24.703,00$ & $40.055,69$ & 51,83 & 4,77 \\
\hline Mean & 0,39 & 2,31 & 3,87 & 2.239 .458 & 0,2401 & $32.010,00$ & $41.779,14$ & 50,63 & 6,63 \\
\hline
\end{tabular}

The second cluster consists of the regions with the best consumer loan performance. This cluster members are performing $25 \%$ better than members in the other cluster. These cluster members have also performed the best economic features. Members of this cluster also have the best economic indicators (see Table 5). For example, members of this cluster have the lowest unemployment rate $(\% 6,63)$. As can be seen from the map in Figure 4, most members are from the northern region and have a lower population density than other cities.

Table 6: Member regions and features of Cluster 3

\begin{tabular}{|c|c|c|c|c|c|c|c|c|c|}
\hline Regions & HLPR & VLPR & OCLRP & POP & $\begin{array}{l}\text { CPI } \\
(\%)\end{array}$ & $\begin{array}{l}\text { PerGDP } \\
\text { (TL) }\end{array}$ & HDI (TL) & $\operatorname{ER}(\%)$ & $\begin{array}{l}\text { UR } \\
(\%)\end{array}$ \\
\hline TR51 & 0,55 & 3,95 & 5,77 & 5.503 .985 & 0,2220 & $48.623,50$ & $56.674,24$ & 47,30 & 10,93 \\
\hline TR52 & 0,41 & 5,69 & 5,83 & 2.457 .522 & 0,2474 & $28.632,00$ & $40.822,39$ & 47,30 & 5,97 \\
\hline TRC2 & 0,74 & 3,85 & 7,62 & 3.768 .205 & 0,2562 & $14.961,00$ & $30.956,07$ & 39,23 & 16,53 \\
\hline Mean & 0,57 & 4,50 & 6,41 & 3.909 .904 & 0,2419 & $30.738,83$ & $42.817,57$ & 44,61 & 11,14 \\
\hline
\end{tabular}

Cluster 3 is the class of the worst-performing members. In particular, personal financial loans, credit cards, and vehicle loan performance are considerably lower than other clusters. Members of this cluster also perform poorly in terms of economic variables. 


\section{MANAGEMENT, BUSINESS \& FINANCE}

Table 7: Member regions and features of Cluster 4

\begin{tabular}{|c|c|c|c|c|c|c|c|c|c|}
\hline Regions & HLPR & VLPR & OCLRP & POP & $\begin{array}{l}\text { CPI } \\
(\%)\end{array}$ & $\begin{array}{l}\text { PerGDP } \\
\text { (TL) }\end{array}$ & HDI (TL) & $\operatorname{ER}(\%)$ & UR $(\%)$ \\
\hline TR61 & 0,47 & 3,57 & 4,74 & 3.137 .694 & 0,2417 & $34.109,00$ & $43.719,23$ & 50,03 & 11,73 \\
\hline TR62 & 0,50 & 3,66 & 7,16 & 4.034 .593 & 0,2630 & $27.448,00$ & $43.157,39$ & 44,63 & 10,77 \\
\hline TR63 & 0,64 & 4,40 & 5,30 & 3.289 .122 & 500 & $22.497,50$ &, 91 & 41,40 & 13,33 \\
\hline TR81 & 0,44 & 4,46 & 4,87 & 1.046 .711 & 0,2541 & $25.525,50$ & $41.827,46$ & 46,60 & 7,93 \\
\hline TRC1 & 0,65 & 4,35 & 5,68 & 2.795 .617 & 0,2511 & $23.713,50$ & $35.427,40$ & 39,80 & 14,07 \\
\hline TRC3 & 0,64 & 3,71 & 6,53 & 2.284 .158 & 0,2557 & $16.895,00$ & $30.590,30$ & 28,90 & 26,73 \\
\hline Mean & 0,56 & 4,03 & 5,71 & 2.764 .649 & 0,2526 & $25.031,42$ & $38.213,62$ & 41,89 & 14,09 \\
\hline
\end{tabular}

The members of cluster 4, which ranks second in the worst performance, is the class with the worst indicators of economic variables. For example, the highest unemployment, the lowest employment, and the highest inflation rate belong to the members of this cluster. The members of this cluster are composed of the provinces in the southern region of Turkey.

\section{Conclusion}

This study has analyzed the performance of consumer loans in Turkey's Banking Sector. For this purpose, cluster analysis was used in the study. According to the results of the analysis, the provinces were classified into four regions according to consumer loan performance similarities in Turkey. According to the results of the analysis, approximately $70 \%$ of the provinces in Turkey performed positively, below average, while $30 \%$ performed negatively above average. It was found that the best cluster consisting of five regions and 17 provinces had the best economic values. The most important feature of these regions is that they have the lowest unemployment and the highest employment rate. The provinces that make up these regions are not the most developed provinces of Turkey. For example, the GDP per capita of 9 cities in these regions and the HDI of 11 cities are below Turkey's average. On the other hand, although some regions have the lowest unemployment and inflation rates, they have been among the worst cluster in terms of consumer loan performance.

Analyzing economic values by making regional classifications can lead to a more meaningful explanation of the characteristics of the regions. This study approached the relationship between the credit performance characteristics of the regions and the country's economic variables from a different perspective. In future studies, it is recommended to regionally analyze the relationship between performance and economic variables and to reveal cause and effect relationships. 


\section{|||||ICMBF}

$2^{\text {nd }}$ International Conference on Advanced Research in

MILAN, ITALY

MANAGEMENT, BUSINESS \& FINANCE

30 October - 1November , 2019

\section{Reference}

[1] Allahverdi, M. and Alagöz, A. (2019). "İllerin Vergi Gelirleri Açısından Sınıflandırılmasında Kümeleme Analizi Kullanımı”, Maliye Dergisi, Sayı 176, 441-473. [2]

Altınöz, Utku (2018). Sorunlu Krediler Bağlamında Türk Bankacılığında Kredi Kayıp

Karşılığının Makroekonomik Değişkenlere Etkisi: Panel Data ve Zaman Serileri Analizi, Hitit Üniversitesi Sosyal Bilimler Enstitüsü Dergisi, 11(1), 63-82.

[3] Banking Regulation and Supervision Agency (BRSA), (2019), FinTurk - Geographical Distribution, Available: https://www.bddk.org.tr/bultenfinturk. [4] BDDK, (2019). "Main Indicators Report Released-March 2019”, Available:

https://www.bddk.org.tr/Announcement/Main-Indicators-Report-Released--March2019/690.

[5] Gürel, E. (2002). Banka Finansal Performansının Ölçülmesi ve Beş Ticari Banka Üzerinde Bir Uygulama, Yayınlanmamıș Yüksek Lisans Tezi, Adnan Menderes Üniversitesi Sosyal Bilimler Enstitüsü, Aydın.

[6] Official Newspaper No: 24884, (2002). Decree Dated 28/8/2002 and No. 2002/4720, Available: https://www.resmigazete.gov.tr/eskiler/2002/09/20020922.htm.

[7] Parasız, İ. (1997). Para Banka ve Finansal Piyasalar Teori ve Politika, Ezgi Kitabevi Yayınları, VI. Baskı, Bursa.

[8] Sarıtaş, Hakan, Uyar Kangallı, G, Sinem ve Gökçe, Atilla (2016). Banka Kârlılığı ile Finansal Oranlar ve Makroekonomik Değişkenler Arasındaki İlişkilerin Sistem Dinamik Panel Veri Modeli ile Analizi: Türkiye Araştırması, Eskişehir Osmangazi Üniversitesi İBF Dergisi, 11(1), 87-108.

[9] TCMB, (2019). Consumer Price Index (2003=100), Available: https://evds2.tcmb.gov.tr/index.php?/evds/serieMarket.

[10] Turkey Statistical Institute (TSI), (2019). Main Statistics,

Available: http://www.turkstat.gov.tr/UstMenu.do?metod=temelist.

[11] Uzunlar, E. (1990). Tüketici Kredileri ve Bankalardaki Uygulama, Atatürk Üniversitesi Iktisadi ve İdari Bilimler Fakültesi Dergisi, 8(3-4), 59-82.

[12] Yüksel, S. and Özsarı, M. (2016). Türkiye'deki Bireysel Krediler ile Enflasyon ve Cari İşlemler Açığı Arasındaki Nedensellik İlişkisinin İncelenmesi, EconWorld2016 Imperial College Proceedings, London, UK, pp. 1-13. 